Інноватика у вихованні. Випуск 12. 2020.

УДК 378.147:81]-057.875-054.6(736.1)

DOI: $\underline{10.35619 / \text { iiu.v1i12.281 }}$

Слуцький Ярослав

кандидат педагогічних наук,

завідувач навчально-методичним кабінетом

Донбаського державного коледжу технологій та управління,

м. Торецьк, Україна

ORCID: 0000-0002-5328-7274

e-mail: yaroslav.slutskiy.mail@gmail.com

\title{
ОСОБЛИВОСТІ ЛІНГВІСТИЧНОЇ ПІДГОТОВКИ ІНОЗЕМНИХ СТУДЕНТІВ В УНІВЕРСИТЕТІ АЛАБАМИ (США)
}

Анотація. У статті проведено аналіз програми лінгвістичної підготовки іноземних студентів в Університеті Алабами. 3'ясовано, що програма містить певні компоненти, засвоєння яких безпосередньо $є$ важливими для розвитку особистості, здатної виконувати повний комплекс взаємодій в новому соціумі, а саме: читати інформацію текстового характеру й різного рівня складності; виконувати діяльність письмового характеру, що необхідно для висловлювання своїх думок не лише у формі усного спілкування; вміння виконувати комунікаційну взаємодію 3 опонентом; мати здатність розуміти почуту інформаційну складову та інтерпретувати іiі у необхідному для подальшої міжособистісної взаємодії форматі. Зазначені компоненти, метою яких $\epsilon$ професійно спрямована підготовка іноземних студентів, виступають у якості допоміжних елементів загального процесу лінгвістичної підготовки. При цьому увага студентів акцентується саме на термінології тієї сфери діяльності, яка була обрана ними при вступі до навчального закладу.

Семінари, що проводилися у межах лінгвістичної підготовки іноземних студентів, були визначені у якості компонента практичного засвоєння отриманих раніше теоретичних знань.

Визначено, що іноземні студенти перед початком підготовчого лінгвістичного процесу виконують тестові завдання, результати яких безпосередньо впливають на їх подальший розподіл на групи відповідно до рівня знань 3 виділених раніше компонентів, серед яких читання, аудіювання i т.н. Однак після початку безпосередньо підготовчого процесу викладач або консультант центру співпраці 3 іноземними студентами, практично ознайомившись $з$ рівнем знань студентів, може їх направити на повторний іспит, що їй допоможе підтвердити або спростувати отримані раніше результати.

Ключові слова: читання, письмова діяльність, аудіювання, говоріння, комунікація, професійна спрямованість, семінар, розподіл відповідно до кваліфікаційного рівня.

Постановка проблеми. Зміни у системі навчання студентів у закладах вищої освіти України вимагають проведення аналізу іноземного досвіду, особливо, коли мова йде про іноземних студентів, а робота з ними потребує іншого освітнього підходу, який одночасно поєднує проведення адаптаційного процесу 3 навчальною діяльністю, складовою частиною якої $\epsilon$ вивчення іноземної мови, що, не може відбуватися у швидкому темпі при досягненні

(C) Слуцький Я., 2020 
якісного рівня навчального процесу. Якщо у цей проміжок часу на особистість негативно впливає культурний шок (природний фактор для іноземних студентів), то вивчення іноземної мови повинно відбуватися в дещо іншому форматі.

Вивчивши досвід закордонних закладів освіти з навчання мови, ми зможемо визначити найбільш ефективні методи для впровадження в процес роботи як 3 іноземними, так і з українськими студентами у вітчизняних закладах освіти.

Аналіз останніх досліджень 3 проблеми. Питання вивчення іноземної мови студентами досліджувалися багатьма вченими де, серед інших засобів, велику увагу зосереджено на використанні аудіювання (Nunan, 1997, Rost, 2013). Деякі дослідники розробляли методики навчання іноземної мови 3 допомогою відео та аудіо засобів, характеризуючи у такий спосіб процес вивчення мови як комплекс засобів медіаосвіти, який може застосовуватися навчальними закладами. Зокрема, Secules, Herron and Tomasello (1992) розглядали ефект використання відеоконтенту під час проведення занять з вивчення іноземної мови. Своєю чергою, Umino (1999) вивчав досвід застосування відеоматеріалів на прикладі вивчення другої іноземної мови японськими студентами.

Застосування читання як методу отримання текстової інформації у якій можуть бути відомості про культурні аспекти країни, яка приймає, досліджував К. Кода (Koda, 2005) та визначив у якості міжлінгвістичного методу.

Але деякі дослідники (Yang, Noels and Saumure, 2006) дійшли висновку, що вивчення іноземної мови має характеризуватися не у якості окремого процесу, а як складова частина міжкультурної адаптації, охоплюючи розвиток навичок соціокультурної взаємодії, що неможливо виконати без опанування іноземної мови.

Мета статті. Дослідити особливості формування лінгвістичної компетенції іноземних студентів в університеті Алабами під час їх участі у Програмі інтенсивного вивчення англійської мови.

Виклад основного матеріалу дослідження. Одним 3 головних елементів лінгвістичної підготовки в університеті Алабами (The University of Alabama) $є$ Міжнародний центр Кепстоун (Capstone International Center), що надає можливість участі у кількох програмах, серед яких найбільш важливою у вивченні іноземної мови $\epsilon$ «Програма інтенсивного вивчення англійської (Intensive English Program)» (Student Handbook. Intensive English program, 2018), яка містить шість рівнів тривалістю шість сесій і проводяться один раз на рік. Сесії розпочинаються в січні, березні, травні, червні, серпні та жовтні тривалістю 6-8 тижнів (весняні та осінні місяці - вісім тижнів, літні - шість), студентам надається можливість навчатися впродовж 20-24 годин на тиждень під час осінніх та весняних сесій, 27 годин на тиждень - під час літніх сесій (Student Handbook. Intensive English program, 2018, p. 8).

Програма розроблена таким чином, щоб студенти могли засвоїти всі матеріали 3 першого по шостий рівень за шість сесій упродовж одного року. Проте варто зауважити, що деяким студентам потрібно більше однієї сесії, аби сформувати нові мовні навички та здійснити перехід на інший рівень. Отже, існує ймовірність необхідності проходження такими студентами одного рівня повторно. Тому, для завершення всієї програми, деяким учням може знадобитися від 12 до 24 місяців (Student Handbook. Intensive English program, 2018, p. 8). 
Для виокремлення особливостей програми варто розглянути іï компоненти, серед яких (Student Handbook. Intensive English program, 2018, p. 9):

1. Читання/письмова діяльність (Reading/Writing).

Програма $з$ розвитку навичок читання та виконання письмової діяльності спрямована на формування у студентів практичних умінь використання англійської мови на рівні достатньому для ефективної діяльності в межах академічних курсів у навчальних закладах США, що потребує здатності академічного читання та написання есе. Програма передбачає набуття студентами достатнього словникового запасу та умінь застосування ефективних стратегій читання відповідно до різних типів завдань. Проведення підготовки студентів, сутністю якої є тісний взаємозв'язок читання та письмової діяльності, сприятиме розвитку спроможності не тільки прочитати текстову інформаційну складову, але й вибудувати та осмислити власні думки у письмовій формі.

2. Говоріння/аудіювання (Speaking/Listening).

Основною метою компоненту говоріння та аудіювання є надання іноземним студентам можливості поліпшити свої навички аудіювання та говоріння англійською мовою, а також формування впевненості у використанні цих навичок. Отже, упродовж навчання студенти формують та закріплюють на практиці навички управління своєю промовою, отримують необхідні інструкції щодо проблеми, пов'язаної з вимовою та вивчають необхідний для проведення якісного комунікаційного контакту запас слів. Означені цілі досягаються при проведенні аудиторних занять, що спрямовані на застосування ситуацій повсякденного типу, які є актуальними при адаптації до життя у США.

3. Структура (Structure).

Основною метою цього компоненту є ознайомлення студентів 3 основними граматичними структурами, які є необхідними для проведення міжособистісної комунікаційної взаємодії. Компонент «Структура» спрямований на підвищення ефективності комунікації, а також сприйняття (читання та аудіювання) i виробництва (говоріння та письмова діяльність) інформації.

4. Культурна комунікація (Culturally Speaking) $є$ компонентом, що характеризується розмовною групою, у рамках якої студенти Інституту англійської мови Університету Алабами проводять зустрічі зі студентами інших підрозділів університету тривалістю дві години на тиждень для комунікаційної взаємодії за тематикою культурного спрямування. Програма є факультативною, однак іiі відвідування $є$ обов'язковим, що впливає на отримання сертифікату Інституту англійської мови (ELI Certificate of Attendance). Групи культурної комунікації діють лише під час осінніх та весняних сесій й відсутні під час літніх сесій.

5. Класи за вибором мають професійне спрямування з вивчення англійської мови, що передбачає також i використання мовної лексики, пов'язаної 3 тематичною спрямованістю класу. Зокрема, студентам пропонується два класи за вибором: англійська мова + бізнес (англійська мова); англійська мова + інженерія.

6. У компоненті семінари часто використовується ротаційний принцип, тобто після закінчення одного семінару для групи розпочинається наступний. Отже, кожна група має можливість брати участь у всіх пропонованих семінарах під час свого навчання.

Загалом, семінари мають практичну підготовчу спрямованість, що дозволяє іноземним студентам отримати необхідну інформаційну складову і сприятиме їх 
подальшому професійному розвитку. Тож, підготовчий процес передбачає участь у таких семінарах, як:

семінар 3 вимови (при вивченні англійської мови не менш важливим аспектом, як, приміром, граматика чи лексика, є правильна вимова іноземних слів. Особливо семінар є важливим для студентів, англійська мова яким не $є$ рідною. Володіння навичками правильної вимови позитивно впливає на адаптаційний процес, тому що особа у такому разі буде почувати себе більш впевнено в процесі комунікаційної взаємодії; зі свого боку опонент зможе вибудувати більш тісну комунікаційну взаємодію 3 іноземним студентом у зв'язку 3 відсутністю наявних відмінностей у культурному та мовному аспектах);

підготовка до іспиту на знання англійської мови TOEFL;

підготовка до тесту IELTS;

підготовка до тесту GRE (необхідний для проходження післядипломного навчання в закладах вищої освіти США).

Семінари, спрямовані на підготовку до іспитів та тестів на знання іноземної мови мають визначальне значення для подальшого розвитку особистості студента в професійному становленні. Наявність сертифікату, що підтверджує певний рівень володіння англійською мовою, $\epsilon$ вагомим елементом для навчання, а також для майбутнього пошуку роботи.

Як зазначалося раніше, Програма інтенсивної англійської мови має дві сесії: осінь/весна та літо. У перший день кожної сесії, нові учасники Інтенсивної програми вивчення англійської мови складають Початковий іспит Інституту англійської мови (ELI Placement Exam), що передбачає тестові завдання (читання, письмова діяльність, граматика) та усну співбесіду (говоріння, аудіювання). Результати цього іспиту враховуються при визначенні відповідного рівня навчання - від одного до шести для кожного студента окремо за трьома напрямами: читання/письмова діяльність, говоріння/аудіювання, структура. Отже, студенти можуть бути розділені на різні рівні в кожному з напрямів підготовки (Student Handbook. Intensive English program, 2018, p. 11).

Зокрема, за напрямом читання/письмо, використовуються два тестових завдання тривалістю 30 хвилин за умови розподілу студентів. Тест 3 читання передбачає прочитання студентами коротких текстових уривків 3 необхідністю надання відповідей на питання, що безпосередньо пов'язані 3 прочитаним уривком. Застосовуються різнорівневі питання до прочитаної інформації - від початкового до середнього та просунутого. Чим більше правильних відповідей дає студент, тим вищим є рівень його розподілу за напрямами. Для виконання письмового тесту студентам необхідно скласти есе із запропонованого питання чи теми. Результати обох тестів сумується в загальну оцінку для кожного студента в процесі визначення його кінцевого рівня розміщення за напрямом читання/письмова діяльність (тобто, якщо рівень знань низький, іноземний студент потрапить до групи з низьким рівнем навичок читання та письмової діяльності).

Ще один 30-хвилинний тест має на меті розміщення студентів за структурним напрямом: для проходження структурного тесту (Structure test) студентам потрібно відповісти на питання з численними варіантами потенційних відповідей, що зосереджені на граматичній структурі англійської мови. Рівні подальшого розподілу відповідають рівню результату тесту за напрямом читання/письмова діяльність. 
Для розподілу за напрямом говоріння/аудіювання кожен студент має взяти участь в індивідуальній усній співбесіді 3 двома викладачами Інституту англійської мови. Результати інтерв'ю стануть основою для розподілу за рівнями кваліфікації напряму говоріння/аудіювання.

Однак варто зауважити, що результати окреслених тестів не є остаточними. Наприклад, упродовж першого дня занять викладач оцінює правильність присвоєння іноземному студенту того чи іншого рівня. Якщо викладач визначить, що студенту було присвоєно занадто низький рівень, він отримає можливість скласти Повторний іспит (Replacement Exam), що проводиться у другій половині першого дня занять.

Повторний іспит складається 3 трьох письмових тестів (читання, письмова діяльність, структура) та усної співбесіди (говоріння, аудіювання). Однак, на відміну від Початкового іспиту, завдання для Повторного охоплюють такий само теоретичний контент, як і завдання для випускних екзаменів 3 кожного рівня розподілу. Згідно 3 результатами Повторного іспиту студенти або залишаться на колишньому рівні, або будуть розподілені на нижчі чи вищі кваліфікаційні рівні.

Варто наголосити, що кожна підготовча програма складається на основі очікувань від кінцевого результату 3 описом того, що студенти зможуть досягнути та які навички опанують після закінчення того чи іншого курсу. Наприклад, в програмі Інтенсивної англійської мови також $є$ визначення «Результатів навчання студентів» (Student learning outcomes), які враховуються викладачами при проведенні занять. Вимоги мають відмінності залежно від напрямів підготовки (читання, письмова діяльність тощо). Отже, можна говорити про такого роду програми, як про засади лінгвістичної підготовки іноземних студентів тому, що вони є основою мовної підготовки особистостей, для яких англійська мова не $є$ рідною (Student Handbook. Intensive English program, 2018, p. 12).

Висновки i перспективи подальших розвідок. Отже, Програма інтенсивного вивчення англійської мови має усі потрібні компоненти для якісного засвоєння іноземними студентами лексики та граматики мови. Наприклад, навчання читанню та письмовій діяльності сприяє отриманню навичок обробки певної інформаційної складової та здатності висловити свої думки у письмовому форматі; говоріння та аудіювання передбачає здатність студента висловити свої думки в усній формі й зрозуміти мову співрозмовника на достатньому рівні для проведення ефективної комунікативної взаємодії; вивчення граматичної структури англійської мови спрямоване на розвиток здатності граматично правильного відтворення своїх думок як у письмовому, так i в усному форматі; культурна взаємодія 3 іншими студентами за допомогою спілкування на відповідну тематику має за мету сформувати культурологічні засади діяльності особистості іноземного студента в академічному та повсякденному просторі під час перебування у Сполучених Штатах; класи 3 вибором мають спеціалізований відтінок та надають теоретичний матеріал, але головне - професійно спрямовану лексику для отримання додаткових знань за певним напрямом; семінари характеризуються додатковими інформаційними та ознайомчими блоками - від навчання студентів правильній вимові до підготовки потенційного проходження мовних іспитів для отримання відповідного сертифіката, який і надає переваги в академічному процесі та в майбутньому пошуку роботи. 
Подальші наукові дослідження варто спрямувати на проведення аналізу різноваріативних програм з лінгвістичної підготовки в Університеті Алабами та в інших закладах вищої освіти США. Як підсумок, здійснити порівняльну характеристику цих програмах 3 виокремленням проблемних елементів визначити найбільш ефективні 3 них та запозичити для застосування у вітчизняній освітній системі роботи з іноземними студентами.

\title{
СПИСОК ВИКОРИСТАНИХ ДЖЕРЕЛ
}

Nunan, D. (1997). Listening in language learning. Language Teacher, 9, p. 47-51.

Rost, M. (2013). Listening in language learning. London: Routledge.

Secules, T., Herron, C., \& Tomasello, M. (1992). The effect of video context on foreign language learning. Modern Language Journal, 76, p. 480-490.

Umino, T. (1999). The use of self-instructional broadcast materials for second language learning: an investigation in the Japanese context. System, 27(1), p. 309-327.

Koda, K. (2005). Insights into Second Language Reading: A Cross-Linguistic Approach. Cambridge University Press.

Yang, R., Noels, K., \& Saumure, K. (2006). Multiple routes to cross-cultural adaptation for international students: Mapping the paths between self-construals, English language confidence, and adjustment. International Journal of Intercultural Relations, 30, p. 487-506.

Capstone International Center. The University of Alabama. URL: http://international.ua.edu/ (Дата звернення: 01.07.2020).

Student Handbook. Intensive English program (2018). Alabama: The University of Alabama. English language Institute.

\section{THE FEATURES OF FOREIGN STUDENTS' LINGUISTIC TRAINING AT THE UNIVERSITY OF ALABAMA}

\author{
Yaroslav Slutskiy \\ PhD in Pedagogy, \\ Head at the Educational and Methodological Center, \\ Donbass State College of Technology and Management, \\ Toretsk, Ukraine \\ ORCID: 0000-0002-5328-7274 \\ e-mail: yaroslav.slutskiy.mail@gmail.com
}

\begin{abstract}
The article analyzes the language training program for foreign students at the University of Alabama. It was found, that the program includes certain components, the assimilation of which is directly important for the development of a person which is capable of performing a full range of interactions in the new society, namely: to read the information of a textual nature and different levels of complexity; to perform the written activities that are necessary for the expression of their own thoughts not only in the form of oral communication; the ability to perform the communication interaction with the opponent; to have the ability to understand the heard information component and interpret it in the necessary format for further interpersonal interaction. The components, which aim is the professionally oriented foreign students' training are emphasized, but they act as auxiliary elements of the general process of linguistic training, focusing the students' attention on the
\end{abstract}


terminology that field of activity, which they chose when entering the educational institution.

Seminars that are held as a part of the foreign students' linguistic training were identified as a component of practical learning of previously acquired theoretical knowledge.

It is noted that foreign students, before the preparatory linguistic process, perform the test tasks, the results of which are directly affect at their further distribution into groups according to the level of knowledge of previously selected components, including reading, listening etc. However, after the start of the preparatory process, the tutor or consultant of the center of cooperation with foreign students, having practically acquainted with the students' level of knowledge, can send them for a replacement exam, which can confirm or refute the previously obtained results.

Key words: reading, writing, listening, speaking, communication, professional orientation, seminar, distribution according to the qualification level.

Стаття надійшла до редакиії 17. 09. 2020 р. 